\title{
THE ANALYSIS ON POSITION OF SECURITY IN ARCHITECTURE
}

\author{
Seyed Mohammad Reza Moosavi \\ Young Researchers and Elite Club, Khomein Branch, Islamic Azad University, Khomein, Iran \\ m moosavi architect@yahoo.com
}

\begin{abstract}
The physical comfort is possible through appropriate access to energy and lack of pollution caused by it and living under favorable climatic conditions at suitable temperature and adequate humidity but in many cases spiritual and mental peace and comfort in human depend on the artificial environment in his/her surroundings. Thus human comfort is measured according to three categories of energy, climate, and artificial environment (building and city). The everyday life environment of human in which $\mathrm{s} / \mathrm{he}$ is immobile and or in move is a space that can be favorable and or intolerable. On the other hand, creating sense of peace and comfort in individual at high levels is related to sense of security in individuals since sense of security may automatically overshadow other human's requirements and in the case of sense of insecurity, most of senses in human will be reduced and or eliminated. Therefore, it is tried in this article to concern with security as one of the foremost environmental effects on human's health. To this end, primarily it has been dealt with definition of urban space on the one hand and security on the other hand. Then, after classification of security, the role of urban spaces in sense of insecurity will be explored and finally a case example is proposed that covers security in world comprehensively.
\end{abstract}

Keywords: Security, Architecture, Urban space, Secure space

\section{INTRODUCTION}

Human is a group of potentials, requirements, and objectives that $\mathrm{s} / \mathrm{he}$ changes his/her surrounding environment with respect to these cases and at the same time s/he is personally influenced by this changed environment. Inter alia, there are some items such as techniques and methods that act such as catalyst in this development and transformation trend. Alternately, this catalyst plays a crucial role in humans' everyday life today; although, it has caused development and improving life level for humans and at the same time it has disrupted mental and social health of human being and it has been followed by a phenomenon called insecurity [1]. Thus, human is the first and greatest victim of technological development and s/he ruthlessly invades the surrounding environment and then is affected by what $s /$ he has made. Whereas the city is deemed as the main space to form human's daily relations thus it can be implied that the city and interior spaces are considered as some of the paramount environmental subsystems that influenced by human behavior and actions and also they affect on human. On the other hand, access to security has been one of the foremost reasons for emerging of city a long time ago. The classic cities included some fences around their site that practically protected from them against entry of aliens and risks [8]. With emerging of industrial revolution and development of industrial products, cities were expanded. Thus, modern cities consist of geographical limit with endless population that are not familiar with each other and there is no social control and monitoring over practice of individuals and unemployment, lack of identity, and hostility may spread to the scene of city and city has displayed some part of its hidden practice under title of hostility and abnormal behaviors and this has jeopardized security for cities and citizens [3].

\section{CONCEPT OF CITY}

Submit Date: 21.06.2016, Acceptance Date: 21.07.2016, DOI NO: 10.7456/1060AGSE/012

Copyright (C) The Turkish Online Journal of Design, Art and Communication 
City denotes a place of accumulation of a lot houses in which people are living. At the same time, the inhabitants of city are deemed as the foremost principle in city since the city is a location where human is born and grows and his / her beliefs and behaviors form and after formation of his/her beliefs, s/he presents history and culture through action and behavior displayed by human [7].

\section{DEFINITION OF URBAN SPACES}

Although urban space is defined by form and body, basically it is the mutual effect among human and space that makes city as meaningful. Therefore, while urban spaces are created as a place for interaction by urban designers, today inappropriate performance of these spaces has been followed by a reality called insecurity.

\section{SECURITY}

In fact, security is something if it lacks, its shortage may be felt so that it is similar to air from this viewpoint. Human's collective life also originates from this need to security. The group gives human sense of comfort that results from loneliness and in fact it guards from him/ her against risks. But on the other hand, this group may make the environment insecure for human per se.

\section{HIERARCHY OF SECURITY REQUIREMENTS AND POSITION INTER ALIA}

Abraham Maslow has presented a hierarchy of needs in order to explain formation of healthy personality in human that it has started from physiologic and physical requirements and it moves toward more complex psychological motives at higher levels. The primary needs such as survival, security and safety, self-reliance, self-actualization, and developmental requirements including perception and aestheticism have been classified as requirements for human in this pyramid. The given requirements should be translated into design language so that John Long has translated them into specific environmental qualities in a model. Based on his model, urban design estimates various human needs as follows [6].

\section{PHYSIOLOGIC REQUIREMENTS}

They include some needs such as food, shelter, and healthcare and the comfort and preservation of balance is met in ecology of location that have been considered in urban design through quality of housing, adequate facilities and equipments [6].

\section{Requirement for security and safety}

It comprises of some needs such as immunity against risks and pollutions, enjoying the needed private site, and observance the subject of pending status that can be estimated through providing quality of safety for passages, possible control and monitoring, penetration and availability and flexibility of spaces.

\section{REQUIREMENT FOR DEPENDENCY AND NEED TO SENSE OF BELONGING (ATTACHMENT) TO A SPECIFIC CLASS AND GROUP}

This need typically leads to encouraging for social interactions through providing social facilities and it is followed by strengthening sense of place, legibility, visual proportion in urban design.

\section{REQUIREMENT FOR SELF-ESTEEM AND SELF-CONFIDENCE}

This need is met by quality and way of ownership of lands and constructions followed by creating sense of individuality and belonging to a certain place and group.

\section{REQUIREMENT FOR REALIZATION OF SELF-ACTUALIZATION OR NEED TO DO CREATIVE ACTIVITY}

This need is met by opportunities that have provided by urban design to identify space and participation in design operation and also through variation in design. 


\section{REQUIREMENT FOR LEARNING AND COGNITION}

This requirement is created according rational motives and it may be responsive by providing possibility for cultural- educational activities by urban design and creating space in environmental qualities.

\section{REQUIREMENT FOR AESTHETICS}

This need is created based on emotional and spiritual motives and it can be responsive by providing facilities for recreational- artistic activities by urban design and creation of urban and good natural landscapes. Accordingly, 'security' as the second basic need in human may play special position among other needs and overlooking this need may be assumed as lack of access to other needs. Thus it seems necessary to recognize definition and identifying the factor may threaten their existence.

\section{DEFINITION OF SECURITY}

(Security) is an Arabic term originates from Arabic root (secure) and it means being at ease and comfort and fearless position. Although security and safety are both derived from the same Arabic cognate but no one should confuse these two terms with each others. The security is a social concept and its use makes sense typically as relevant to city, community, and group while safety means avoidance from risk and for living in health and it is often used individually [5].

It has mentioned in great book of in which about eleven thousand Islamic narratives have been gathered from Imam Ali (PBUH) and a lot of very marvelous and constructive narratives have implied about security and particularly based on psychological dimension so it is referred to some them:

(No bounty is more pleasant than security)

(The worst cities where there is no security and green space)

DIFFERENCE IN SENSE OF SECURITY AMONG VARIOUS INDIVIDUALS

Based on definition of security, when one's life is threatened by a risk or if some conditions govern over the society in which the individual does not feel sense comfort and being secure his/her security may be endangered. The rate of security is not the same for all inhabitant members in a city. In fact, the amount of security sense is much greater in men, adults, well-to-do persons, literate and employed ones, dwellers at the center of city and believers in the current religion than in women, children, low- income persons, illiterate or less- literate individuals, unemployed and outskirt dwellers [4].

\section{THREE FIELDS OF SECURITY}

Humans' activities are done in response to requirements of three fields i.e. soul, ego or mind, and body. Also both basic and constituent elements of architecture and features of final and created form are related to proportionally to one, two, and or three above fields and the optimum state is when there is balance among relevance of architecture to these three domains. Some subjects may be proposed in physical domain such as dimensions, proportions, and materials. Human's mental and subjective perception and architectural element will be addressed in domain of sensual perception and spiritual symbols, mysteries, and concepts and metaphysical relationship are suggested in domain of intrinsic concept. As a result, security is also explored in terms of three degrees in architecture:

Physical security: Including physical needs such as requirements for food and housing and so forth;

Mental security: consists of sensual needs including freedom and egotism; and 
Spiritual security: comprising of soul related needs such as relationship with origin of existence

Indeed these items are assumed as various levels of human's affection by security or its lack and in other words insecurity also in turn affects on the higher levels at any level and from other aspect. For example, some factors such as environmental stresses initially threaten physical security and mental security of individual in long run. And even conversely mental insecurity will be followed by creation of material and physical consequences [4].

\section{THREATENING FACTORS FOR PHYSICAL AND MENTAL SECURITY}

These factors includes some items that directly and indirectly threaten physical and mental security for human among of them one can refer to drugs trafficking and purchase and sale, sexual corruption and violence against females and children, crime, pollutions and stressful environmental factors, hostility, and inappropriate urban designs and planning. Inter alia, it is dealt with way of effect of some of these factors on security.

\section{STRESSFUL ENVIRONMENTAL FACTORS}

Stressful environmental factors are some agents that cause loss of individual's potentials as well as emerging hostility through creation of stress and tension in person in long run and thereby they will influence in rising crime and offence and creating insecure environment. Some of these factors such as traffic and noise due to presence of population and high crowd, presence of automobile and other public transportation vehicles may have instant and immediate effect on individual's efficiency but in some others such as air pollution or higher level of heat and humidity their consequences will appear in long term [4].

\section{FEATURES OF ACCESS AND COMMUNICATIVE NETWORKS}

Less accessibility removes well-being and liveliness from city. Of course, a lot of communications between spaces will increase crime as well. But, some factors such as appropriate accessibility structure, connection networks in good streets and sidewalks, transparent view horizon in street, security in sidewalk by deletion of space capable for hiding, clear access, and lack of public access to back of building will increase sense of security. On the other hand, some factors such as lack of suitable street alignment, lack of traffic light, narrow sidewalks or merged into motorway, banked streets, one-way and narrow and less-enlightened streets, L- and T- form streets will create insecurity in environment [4].

\section{VISUAL POLLUTION}

The presence of any disturbance and distortion in physical appearance of city is called visual pollution. Inappropriate landscape of city and the pollutions created by people or officials in city may gradually reduce number of population at that site and this pave the way for perpetration of crime. These pollutions include worn and dirty panels, dust bin, the intrusive transport and traffic signs and panels, abandoned half-built constructions, lack of coordination in materials, broken windows and panels and creation of disorder in skyline [5].

\section{COLOR POLLUTION}

The colors may affect positively or negatively on human's mind. We witness in old buildings how they used a composition of blue turquoise and brown or khaki color that can create sense of security in human.

\section{JOB SECURITY}

If someone is not ensure about continuity of his/ her job and thinks about this possibility to lose his/her job that person does no feel sense of job security. Job insecurity may inflict numerous social and economic damages to society including lack of motive for work, tendency to use nepotism 
techniques in workplace and non- creation of total quality management system in business that are considered as consequences of job insecurity [11].

\section{ECONOMIC SECURITY}

The economic security is a status beyond job security and it takes place when economic instability governs over the society. Non- fixed rates and prices, lack of tendency to investment, subsequent and unreasonable changes in economic regulations and tariffs etc are some cases of economic insecurity.

\section{SCALE}

Aristotle argues that a city should not be so big that the voice of public assistance- seeking is not heard behind it. The metropolises include endless and horrendous spaces that seemed to be insecure compared to cities with human scale.

\section{DIFFERENCE OF CLASSIC AND MODERN USE OF ALLEY}

The old localities were the places for playing of children and interaction between female householders and in fact there was a type of leisure for individuals that it was defined within framework of use of alleys space. But today through human's behavioral change, transport of women and children is followed by risk and sense of fear in that locality during some hours in day and night.

\section{URBAN CHESSBOARD DESIGN}

This type of design causes creating clearance spaces in cities. With respect to urbanism new structure, the new technique of housing and settlement in flats in which the persons are strangers and not familiar with each other, a criminal may easily enter in these chessboard designed textures and commit his/her crime and then exit from any point that $\mathrm{s} /$ he likes. Chessboard (staggered) design is problematic in terms of traffic as well and it may jeopardize security for individuals.

\section{HIGH DENSITY CONSTRUCTION}

The localities with high-dense population or those localities which include low-income persons are often subjected to crimes.

\section{RECESS OF CONSTRUCTIONS}

Recess of buildings causes creating space out of view in which crime perpetration will be exacerbated.

\section{USE INTERFERENCE}

If the architectural uses interfere with each other and residential, commercial, administrative and industrial uses and otherwise are combined with each other some different individuals may move through the site that they have no perfect knowledge about each other. Such an environment prepares very suitable ground for hiding of criminals and crime perpetration [6].

\section{SPIRITUAL SECURITY}

The security is one of important spiritual features in Islamic community. From Islamic viewpoint, spiritual security or faith to God is deemed as the main source of security [10]. Interaction among divine faith and security is well manifested in Holy Quran and it has been persisted in this fact that the real security and its main source will realize in spiritual security and this is also in faith to God and acquiring divine consent. This security is the root of all securities and comforts. Accordingly, as it expressed in Holy Quran (Anaam Sura 6: 81-82): “... which then of the two parties is surer of security, if you know? Those who believe and do not mix up their faith with iniquity, those are they who shall have the 
security and they are those who go aright. ${ }^{1 "}$ - Quran assumes security as one of divinely descended blessings for God-believers and as a factor to improve their faith [2].

\section{THE EFFECTIVE FACTORS ON CREATION OF SPIRITUAL SECURITY IN URBAN SPACES}

1- $\quad$ Greetings (salutations) among individuals

2- $\quad$ Giving help to each other

3- $\quad$ To perform prayers

4- The existing mosques and Takaya (Islamic mourning places), Hosseiniyeh sites, Shrines, and Quranic training centers

5- $\quad$ Paying attention to reflection of advertisement boards in which they exploited unfairly from Quranic verses or Islamic traditions (Hadith) for their promotion to spiritual insecurity

\section{REVIEW CASE STUDY IN SECURITY IN DIVINE SECURE SANCTUARY (حرم (من الهى)}

The harem (secure site) of God's house (Mecca) includes certain zone that its distance from border of Kaaba varies from different directions. Harem (sanctuary area) is limited to Tanaim Mosque from north and northwest sides in Medina path, and from south and southeastern side to Okaishie in Yemen route, and to Al-Juranah (جعرانه) near Mena and Mashaar Al-Haram lands and in Taif path and also to Hudaibiyyeh (حدييه) from westward in Jeddah route [2].

\section{WHY GOD'S HOUSE IS CALLED SECURE SANCTUARY}

Mecca is Mother of Cities and pattern of utopia and based on Quranic verses this land should be a secure place for those who live there as well as for the people that come there from outside. Even it was narrated that those ones who have committed crime outside this secured place and then go into this Harem they will not be sentenced as long as they are present in this secure site. Divine sanctuary is also secure for animals and no one has any right to hunt wild animals and birds that are placed within the area of sanctuary. It is noteworthy that prohibition of hunting in secure area of Harem is not exclusively allocated to sacred month of Muharram but it includes all months other than Muharram within secure sanctuary while the prohibition of hunting is a divine trial for humans. This security is due to the effect of blessing of Abraham's (PBUH) prayer and three requests from God as founder of Kaaba [2].

1- Physical security: land cultivation

“...Our Lord! Surely I have settled a part of my offspring in a valley unproductive of fruit near Thy Sacred House..." "(Abraham Sura 14: 37)

2- Mental security: establishment of security

“...My Lord! Make this city secure... 3" (Abraham Sura 14: 35)

3- Spiritual security: Avoidance from idolatry

“...And save me and my sons from worshipping idols ..." (Abraham Sura 14:35) 


\section{CONCLUSION}

Sense of security is deemed as one of the spiritual needs for human and as the paramount parameter in quality of urban spaces. Design of urban secure environments and improvement of environmental quality of residential zones is effective in reducing urban crimes to great extent and it is assumed as one of the efficient factors in occurrence of crime in social and living environment in such a way that type and quality of architecture and urbanism may highly influence in reduction or increase occurrence of crimes. Overall, perhaps it can be implied that one is secure and feels sense of security that what $\mathrm{s} /$ he has identified legally as an ethical rule for oneself is considered as valid and respected by others at the same time. As a result, urban security is in fact a legal group that is benefitted by an individual as a human city inhabitant there.

\section{REFERENCES}

Asgharian Jedi A, The relationship among fear and architecture, two Quarterlies of Soffeh (Shade), vol. 39, 2004

Javadi Amoli, A, A sip of hajj chalice, 2008, Mashaar Pub

Dehghan, M, Urbanism and rising trend of crimes, Municipalities Journal, vol. 41, 2002

Salehi, N \& Ismaeli S, Environmental features of secure urban spaces, Publication of urbanism and architectural studies and researches organizational center, 2009

Ali Abadi, J, Role of urban spaces in providing security in society, Municipalities Journal, vol. 41, 2002

Mortazavi, SH, Environmental psychology and its application, Publication of Shahid Beheshti University, 2008

Moosavi, Minoo, Vandalism in public spaces- urban transportation, Municipalities Journal, vol. 41,2002

Naghizadeh, M, Perception of urban beauty and identity in light of Islamic doctrine, Publication of cultural- recreational organization of Isfahan municipality, 2008

Naghizadeh, M, Islamic architecture and urbanism (theoretical bases), 2006, Rahian Pub

Hashemi, Ameneh (2011), Security and social health as a brand of Islamic city with approach to sustainable housing architecture, $3^{\text {rd }}$ national conference on urban civil engineering, Sanandaj, Islamic Azad University, Sanandaj branch

Bashiri, Sajad, Zare Leila \& Ziabakhsh, Neda, (2014), Analysis on security of urban environment and architecture in terms of psychology, National conference on architecture and urban landscape, Mashhad, International institute for architectural and urbanism studies of Mahraz Shahr (city) 